\title{
Prawo do zasiłku dla bezrobotnych - uwagi inspirowane treścią encykliki Laborem excercens
}

Minęło ponad 30 lat od ogłoszenia przez papieża Jana Pawła II encykliki Laborem exercens. Mimo to zawarte w niej wzorce i postulaty nie tracą na wartości, a nawet nabierają szczególnego znaczenia w dobie kryzysu gospodarczego. Ciągła i narastająca obawa części społeczeństwa przed utratą pracy powoduje, że świadomość funkcjonowania skutecznego systemu zabezpieczenia na wypadek bezrobocia oraz realizacja przez państwo efektywnych programów przeciwdziałania bezrobociu, daje przynajmniej minimalne poczucie bezpieczeństwa socjalnego.

W encyklice ważne miejsce zajmuje kwestia bezrobocia oraz związana z nim potrzeba łagodzenia jego skutków poprzez wypłatę świadczeń. W rozważaniach na ten temat kluczowe miejsce zajmuje pojęcie bezrobocia i bezrobotnego. Bezrobocie zostało określone jako „brak zatrudnienia dla uzdolnionych do tego podmiotów pracy"1. Podmiotami, o których tu mowa są pracownicy, którzy mają umiejętności, kwalifikacje niezbędne do wykonywania pracy społecznie użytecznej. Są także zdolni i gotowi do podjęcia takiej pracy, jednak z przyczyn od siebie niezależnych nie mogą jej wykonywać. Taką sytuację encyklika stanowczo potępia, a występowanie zjawiska bezrobocia w każdym społeczeństwie jest klęską. Szczególnie, gdy dotyka osób młodych, wkraczających na rynek pracy, które po latach nauki zdobyły kwalifikacje do wykonywania pracy, a mimo to stają się bezrobotnymi. Ważną rolę w tej sytuacji odgrywają tzw. pracodawcy pośredni, czyli „zespół instytucji krajowych i międzynarodowych” (LE 18). W kwestii bezrobocia

* Dr Katarzyna Jaworska, Katedra Prawa Pracy i Zabezpieczenia Społecznego, Wydział Prawa i Administracji, Uniwersytet Warmińsko-Mazurski, ul. Warszawska 98, 10-702 Olsztyn.

1 Jan PaWet II, Encyklika o pracy ludzkiej, Laborem exercens, pkt 18, Warszawa 1982. Wszystkie cytaty opatrzone skrótem tytułu (LE) pochodzą z tego wydania. 
papież Jan Paweł II nałożył na pracodawców pośrednich dwa obowiązki. Pierwszym z nich jest prowadzenie takich działań, aby każdy, kto chce pracować, mógł znaleźć odpowiednie zatrudnienie, drugim natomiast jest obowiązek wypłaty odpowiednich świadczeń niezatrudnionym pracownikom. Świadczenia te powinny być w takiej wysokości, aby bezrobotny mógł utrzymać siebie i swoją rodzinę, a więc w wysokości co najmniej minimum socjalnego. Obowiązek wypłaty tych świadczeń wynika z określonej w encyklice zasady - „prawa do życia i utrzymania" (LE 18).

Na tym gruncie powstaje pytanie, czy polski ustawodawca uwzględnił w krajowym systemie zabezpieczenia społecznego na wypadek bezrobocia wzorce zawarte w encyklice Laborem exercens? Aby odpowiedzieć na tak postawione pytanie, konieczne jest przeanalizowanie warunków nabycia prawa do zasiłku dla bezrobotnych oraz zbadanie, czy świadczenie to jest odpowiednie, czyli dające możliwość utrzymania bezrobotnego i jego rodziny.

W polskim porządku prawnym kwestię wypłaty świadczeń z tytułu bezrobocia reguluje ustawa $z$ dnia 20 kwietnia 2004 r. o promocji zatrudnienia i instytucjach rynku pracy ${ }^{2}$ (dalej: u.p.z.), która charakteryzuje się pewnego rodzaju dualizmem w ograniczaniu prawa do nabycia zasiłku dla bezrobotnych. $Z$ jednej strony jest to definicja bezrobotnego, zawarta w art. 2 ust 1 pkt. 2 u.p.z., ponieważ tylko osoba spełniająca warunki określone $w$ tym przepisie może nabyć status bezrobotnego i ubiegać się o przyznanie zasiłku. $Z$ drugiej strony są to warunki nabycia prawa do zasiłku dla bezrobotnych, o których mowa w art. 71 u.p.z.

Przyjęta przez legislatora koncepcja budowy prawnego pojęcia bezrobotnego jest konsekwentnie realizowana od pierwszego ustawodawstwa ${ }^{3} \mathrm{w}$ tym zakresie wprowadzonego po rozpoczęciu transformacji systemowych w 1989 r. Zakłada ona, że definicja bezrobotnego zbudowana jest $z$ dwóch części ${ }^{4}$. Pierwsza z nich zawiera przesłanki pozytywne, które muszą być spełnione, aby uzyskać status bezrobotnego. Druga natomiast mieści w sobie szereg przesłanek negatywnych, które mimo spełniania tych pierwszych uniemożliwiają nabycie statusu bezrobotnego.

W związku z tym, że normatywne pojęcie bezrobotnego jest skonstruowane w bardzo zawiły i kazuistyczny sposób, zwrócę w tym miejscu uwagę tylko na kilka aspektów tej definicji ${ }^{5}$. Będą to przesłanki, które w mojej ocenie oddalają status bezrobotnego od historycznie z nim powiązanego statusu pracowniczego. Wynika to z faktu, który papież Jan Paweł II wskazał w encyklice Laborem exercens,

2 Dz. U. 2008, nr 69, poz. 415, ze zm.

3 Ustawa z dnia 29 grudnia 1989 r. o zatrudnieniu, Dz. U. nr 75, poz. 446.

4 Z. Góral, Przepisy ogólne, [w:] Ustawa o promocji zatrudnienia i instytucjach rynku pracy. Praktyczny komentarz, red. Z Góral, Warszawa 2011, s. 46; A. Kosut, Komentarz do ustawy o zatrudnieniu i przeciwdziałaniu bezrobociu, Gdańsk 1996, s. 17.

5 Więcej na temat definicji bezrobotnego zob.: Z. Góral, Przepisy ogólne..., s. 45 i n.; A. Kosut, Komentarz..., s. 16 i n.; W. Sanetra, Zatrudnienie i bezrobocie. Przepisy i komentarz, Warszawa 1993, s. 28 i n. 
że bezrobotnym jest niezatrudniony pracownik (LE 18). W związku z tym jest to osoba, która wykonywała wcześniej pracę zarobkową, ale ją utraciła. Dlatego można w tym miejscu stwierdzić, że encyklika stoi na stanowisku, że ochronie podlega bezrobocie pełne. Pojęcie pełnego bezrobocia znajduje się $w$ konwencji 168 Międzynarodowej Organizacji Pracy (MOP) ${ }^{6}$ dotyczącej popierania zatrudnienia i ochrony przed bezrobociem ${ }^{7}$. Zgodnie $z$ art. 10 ust. 1 konwencji, bezrobocie to zjawisko polegające na utracie zarobków z powodu niemożności znalezienia odpowiedniego zatrudnienia, w przypadku osób zdolnych do pracy, będących do dyspozycji i faktycznie poszukujących pracy (full unemployment).

Z pierwszej części ustawowej definicji bezrobotnego wynika, że za bezrobotną może być uznana osoba, która m.in. jest niezatrudniona i nie wykonuje innej pracy zarobkowej, jest zdolna i gotowa do podjęcia zatrudnienia lub innej pracy zarobkowej w pełnym wymiarze czasu pracy i poszukuje takiej pracy, co do zasady nie uczy się w szkole oraz wypełniła obowiązek rejestracyjny we właściwym powiatowym urzędzie pracy. Przesłanki te pokrywają się w znacznej mierze ze standardami międzynarodowymi w tym zakresie. Konwencja 168 MOP wskazuje na takie przesłanki, jak: zdolność do pracy, dyspozycyjność (gotowość), faktyczne poszukiwanie pracy, brak odpowiedniego zatrudnienia oraz utrata zarobków (brak zarobków). Przesłanka braku odpowiedniego zatrudnienia znalazła się w polskim ustawodawstwie wśród warunków nabycia prawa do zasiłku dla bezrobotnych, dlatego będzie o niej mowa w dalszej części opracowania. Natomiast co do przesłanki utraty zarobków, jest ona poniekąd powiązana z nabyciem prawa do zasiłku. Jednak brak wyeksponowania jej jako warunku nabycia statusu bezrobotnego powoduje oddalenie polskiej regulacji od założenia, że ochrona przed negatywnymi skutkami bezrobocia związana jest z szeroko rozumianą grupą pracowniczą, a za bezrobotną powinna być uznana tylko osoba, która wykonywała wcześniej pracę. Wyjątkiem od tego założenia, w większości państw Unii Europejskiej, jest system wypłaty świadczeń dla bezrobotnych absolwentów ${ }^{8}$.

W drugiej części definicji bezrobotnego ustawodawca zawarł szereg przesłanek negatywnych nabycia tego statusu. Ich oczywistą funkcją jest ograniczenie kręgu bezrobotnych kosztem osób, które wypełniają przesłanki pozytywne, jednak $z$ woli ustawodawcy nie mogą zostać uznane za bezrobotne. Generalnie przesłanki te są głównie związane z uzyskiwaniem przychodu albo z brakiem zdolności i gotowości do podjęcia zatrudnienia lub innej pracy zarobkowej. Katalog świadczeń, których pobieranie lub samo nabycie do nich prawa uniemożliwia uzyskanie statusu bezrobotnego jest bardzo rozbudowany. W pierwszej kolejności należy

${ }^{6}$ Zob. T. Wóscik, Recepcja „Laborem exercens” przez Międzynarodową Organizację Pracy, [w:] Praca kluczem polityki społecznej, red. J. Mazur, Lublin 2006, s. 237.

7 Tekst konwencji w języku polskim, www.mop.pl/doc/html/konwencje/k168.html [dostęp: 16.10.2013].

8 Zob. G. Uścińska, Ubezpieczenia społeczne i pomoc w razie bezrobocia w ustawodawstwach państw UE. Analiza porównawcza, Warszawa 2011, s. 7 i n. 
wskazać w tym miejscu na nabycie prawa do emerytury. Ustawodawca związał ten warunek nie $z$ faktem pobierania świadczenia, lecz z nabyciem do niego prawa, które musi zostać potwierdzone przez odpowiedni organ. Na marginesie warto zauważyć, że przesłanka ta koreluje z górną granicą wieku umożliwiającą nabycie statusu bezrobotnego, która jest jednocześnie ustawowym wiekiem emerytalnym $^{9}$. Przesłanką negatywną nabycia statusu bezrobotnego jest także nabycie prawa do renty z tytułu niezdolności do pracy, renty szkoleniowej, renty socjalnej, renty rodzinnej w wysokości przekraczającej połowę minimalnego wynagrodzenia. W rozważaniach na temat tej przesłanki należy zauważyć, że z pobieraniem wskazanych świadczeń wiąże się brak gotowości do podjęcia zatrudniania w pełnym wymiarze czasu pracy oraz niezdolność do pracy, niekiedy nawet całkowita.

Kolejnym zabiegiem ustawodawcy mającym na celu ograniczenie zakresu podmiotowego pojęcia bezrobotnego jest uniemożliwienie nabycia tego statusu osobom, które po ustaniu zatrudnienia, innej pracy zarobkowej lub zaprzestaniu prowadzenia pozarolniczej działalności pobierają: nauczycielskie świadczenie kompensacyjne, zasiłek przedemerytalny, świadczenie przedemerytalne, świadczenie rehabilitacyjne, zasiłek chorobowy, zasiłek macierzyński lub zasiłek w wysokości zasiłku macierzyńskiego. Osoby pobierające te świadczenia, podobnie jak w poprzednich przypadkach, ze względu na stan zdrowia lub sytuację osobistą nie są zdolne i gotowe do wykonywania pracy w pełnym wymiarze czasu pracy.

Nie tylko pobieranie świadczeń z ubezpieczenia społecznego powoduje dyskwalifikację przy ubieganiu się o nabycie statusu bezrobotnego. Skutek taki związany jest też z pobieraniem zasiłku stałego ${ }^{10}$ oraz świadczeń przewidzianych w ustawie o świadczeniach rodzinnych ${ }^{11}$. Chodzi tu o świadczenie pielęgnacyjne oraz o dodatek do zasiłku rodzinnego z tytułu samotnego wychowywania dziecka i utraty prawa do zasiłku dla bezrobotnych na skutek upływu okresu jego pobierania.

Przy wprowadzeniu powyższych ograniczeń wydaje się, że ustawodawca wyszedł z założenia, zgodnie z którym osobom niewykonującym pracy, ale posiadającym źródło utrzymania w postaci świadczeń z ubezpieczenia społecznego lub pomocy społecznej status bezrobotnego nie jest potrzebny ${ }^{12}$. Dotyczy to nawet sytuacji, w których wysokość pobieranego świadczenia nie zaspokaja podstawowych potrzeb życiowych, a osoba je pobierająca aktywnie poszukuje zatrudnienia. Takie założenie za bardzo odchodzi od bezrobocia rozumianego jako przymusowy stan spowodowany utratą pracy i rozluźnia historyczną więź między statusem pracownika a statusem bezrobotnego. Trzeba zauważyć, że słusznie wskazuje się w przytoczonych wyżej aktach prawa międzynarodowego, że status

${ }_{9}$ Zob. art. 24 ust. 1a i 1b oraz art. 27 ust. 2 i 3 ustawy z dnia 17 grudnia 1998 r. o emeryturach i rentach z Funduszu Ubezpieczeń Społecznych, Dz. U. 2009, nr 153, poz. 1227, ze zm.

10 Zob. art. 37 ustawy z dnia 12 marca 2004 r. o pomocy społecznej, tekst jedn.: Dz. U. 2009, nr 175, poz. 1362, ze zm.

11 Ustawa z dnia 28 listopada 2003 r. o świadczeniach rodzinnych, tekst jedn.: Dz. U. 2006, nr 139, poz. 992, ze zm.

12 A. Kosut, Komentarz...., s. 18. 
bezrobotnego jest głównie związany z utratą wynagrodzenia w związku z brakiem możliwości wykonywania pracy, a nie z samym brakiem środków do życia. Innym problemem związanym z tym zagadnieniem jest słuszność wprowadzenia takich ograniczeń w nabyciu statusu bezrobotnego. Jak już była mowa, generalnie pobieranie któregokolwiek z tych świadczeń powoduje, że zainteresowany nie legitymuje się zdolnością lub/i gotowością do podjęcia zatrudnienia lub innej pracy zarobkowej. A przecież te przesłanki znalazły się w pierwszej części definicji bezrobotnego i tylko pod tym kątem należałoby dokonywać oceny zasadności rejestracji w charakterze bezrobotnego.

Stanowisko ustawodawcy, zgodnie z którym bezrobotnym jest osoba, która nie ma środków utrzymania, znajduje swoje potwierdzenie w kolejnych przesłankach negatywnych, warunkujących nabycie statusu bezrobotnego. Jedną z nich jest uzyskiwanie przychodu w wysokości przekraczającej połowę minimalnego wynagrodzenia za pracę. Zakaz ten nie dotyczy przychodów uzyskanych z tytułu odsetek lub innych przychodów od środków pieniężnych zgromadzonych na rachunkach bankowych. Nie oznacza to jednak, że bezrobotny może uzyskiwać przychód w tej wysokości pochodzący z wykonywania pracy zarobkowej. Pojęcie przychodu zostało dookreślone w słowniczku do u.p.z. Zgodnie $z$ art. 2 ust. 1 pkt 24 u.p.z., oznacza przychody z innego tytułu niż zatrudnienie, inna praca zarobkowa, działalność gospodarcza, zasiłek lub inne świadczenie wypłacane z Funduszu Pracy, podlegające opodatkowaniu na podstawie przepisów o podatku dochodowym od osób fizycznych. Pamiętać jednak należy, że wśród przesłanek pozytywnych nabycia statusu bezrobotnego znajduje się wymóg niezatrudnienia i niewykonywania innej pracy zarobkowej. Oznacza to, że o przeciwwskazaniach do uzyskania tego statusu decyduje w pierwszej kolejności pojęcie zatrudnienia lub innej pracy zarobkowej, powodując, że uzyskiwanie przychodu z pracy jest przesłanką mniej znaczącą ${ }^{13}$. Znalazło to swoje potwierdzenie w wyroku Naczelnego Sądu Administracyjnego ${ }^{14}$, zgodnie z którym twierdzenia, jakoby $z$ literalnego brzmienia tego przepisu wynikało zezwolenie osobie bezrobotnej na uzyskiwanie przychodów z tytułu wykonywania umowy zlecenia, umowy agencyjnej czy umowy o dzieło (przy jednoczesnym zachowaniu warunku, aby nie przekraczały one miesięcznie wysokości połowy minimalnego wynagrodzenia za pracę) są nieuprawnione. Nad słusznością całkowitego zakazu zarobkowania przez bezrobotnych należy przez chwilę się zatrzymać. W mojej ocenie zezwolenie bezrobotnym, szczególnie tym bez prawa do zasiłku, na wykonywanie prac dorywczych, krótkoterminowych, mogłoby wpłynąć pozytywnie na ich postawę i sytuację na rynku pracy. Korzyści płynące z takiego rozwiązania mogłyby być ogromne. Bezrobotny mógłby sprawdzić w praktyce umiejętności

${ }^{13}$ A. Kosut, Nowe regulacje prawne z zakresu promocji zatrudnienia i instytucji rynku pracy (wybrane zagadnienia), „Praca i Zabezpieczenie Społeczne” 2006, nr 2, s. 26.

14 Wyrok Naczelnego Sądu Administracyjnego z dnia 6 maja 2008 r., I OSK 1123/07, LEX nr 471501, www.orzeczenia.nsa.gov.pl/doc/7EDB4CBBB7 [dostęp:15.10.2013]. 
nabyte podczas szkolenia zorganizowanego chociażby przez powiatowy urząd pracy, zaś pracodawca po sprawdzeniu kwalifikacji i umiejętności bezrobotnego mógłby w przyszłości zatrudnić go w pełnym wymiarze czasu pracy. Oczywiście należy zdawać sobie sprawę, że taka możliwość mogłaby prowadzić do nadużyć. Jednak bilans zysków i strat, w mojej ocenie, ciągle byłby dodatni. $Z$ drugiej strony brak możliwości zarobkowania, nawet w ograniczonym zakresie, może działać demobilizująco na osoby bezrobotne, które nie będą poszukiwały nawet pracy o charakterze doraźnym na podstawie umowy o dzieło, aby nie utracić swojego statusu' ${ }^{15}$.

Innym elementem definicji bezrobotnego, który oddala status bezrobotnego od statusu pracowniczego, jest rejestracja w charakterze bezrobotnego osoby wykreślonej z ewidencji działalności gospodarczej. Możliwość ta może budzić pewne wątpliwości, ponieważ ochrona przed bezrobociem historycznie dotyczyła oraz obecnie dotyczy przede wszystkim szeroko rozumianej klasy pracowniczej. Tymczasem za bezrobotnego może zostać uznana osoba, która w ramach prowadzonej przez siebie działalności gospodarczej pełniła rolę pracodawcy ${ }^{16}$. Jednak nie można pominąć faktu, że coraz powszechniejsze na rynku pracy jest samozatrudnienie, które nie jest związane z zatrudnianiem pracowników, ale w ramach którego praca świadczona jest na rzecz określonego podmiotu, w sposób do złudzenia przypominający stosunek pracy ${ }^{17}$.

W encyklice Laborem exercens papież Jan Paweł II wskazał na obowiązek wypłaty bezrobotnym odpowiednich świadczeń, które pozwoliłby na utrzymanie bezrobotnego i jego rodziny. Zasiłek dla bezrobotnych ma prawie wiekową tradycję ${ }^{18} \mathrm{w}$ polskim systemie prawnym, mimo to doświadczenia $\mathrm{z}$ ostatniego dwudziestolecia wskazują, że ustawodawca ciągle poszukuje finalnego modelu zabezpieczenia społecznego na wypadek bezrobocia. Główną funkcją zasiłków dla bezrobotnych jest zagwarantowanie niezbędnego dochodu po utracie zatrudnienia ${ }^{19} \mathrm{i}$ w okresie poszukiwania nowego, dzięki któremu bezrobotny wraz z rodziną będzie mógł przetrwać ten trudny okres. Jednocześnie wysokość zasiłku powinna być ustalona na takim poziomie, aby mobilizować bezrobotnego do jak najszybszego ponownego podjęcia zatrudnienia ${ }^{20}$. Jednak nie można powiedzieć, że zasiłek zastępuje wynagrodzenie za pracę w rozumieniu przepisów Kodeksu

${ }^{15}$ A. Kosut, Niektóre problemu związane z pojęciem prawnym bezrobotnego, „Praca i Zabezpieczenie Społeczne" 1999, nr 12, s. 29.

16 Z. Góral, Prawne pojęcie bezrobotnego, „Studia Prawno-Ekonomiczne” 1996, T. LIII, s. 31.

17 Zob. P. Prusinowski, Umowne podstawy zatrudnienia, Warszawa 2012, s. 45 i n.

18 Pierwszą ustawą regulującą wypłatę zasiłków z tytułu bezrobocia była ustawa tymczasowa z dnia 4 listopada 1919 r. o doraźnej pomocy dla bezrobotnych, Dz. U. 1919, nr 89, poz. 483.

${ }^{19} \mathrm{~S}$. Golinowska, Zasitki dla bezrobotnych. Motywacja do wyjścia z bezrobocia czy pozostania w nim?, [w:] Zmiany i reformy w systemie zabezpieczenia społecznego w kierunku wzrostu indywidualnej odpowiedzialności, red. S. Golinowska, Warszawa 1999, s. 107.

20 H. ZARYCHTA, Funkcja dochodowa i motywacyjna zasiłków dla bezrobotnych w Polsce, „Praca i Zabezpieczenie Społeczne" 1998, nr 3, s. 4. 
pracy $^{21}$ lub stanowi jego surogat ${ }^{22}$. Nie jest także uprawnieniem ze stosunku pracy realizowanym po ustaniu tego stosunku ${ }^{23}$. Mimo to podlega wzmożonej ochronie w postępowaniu egzekucyjnym ${ }^{24}$. Zgodnie z obowiązującymi przepisami, jest świadczeniem publicznoprawnym finansowanym z funduszu celowego - Funduszu Pracy. Środki na jego wypłatę pochodzą z obowiązkowych składek, które są opłacane za pracowników i osoby aktywne zawodowo, przez pracodawców i zleceniodawców, w wysokości 2,45\% wynagrodzenia lub zapłaty. Składki pobierane są co miesiąc przez Zakład Ubezpieczeń Społecznych łącznie ze składkami na ubezpieczenia społeczne, a następnie, po potrąceniu kosztów związanych z poborem składek w wysokości 0,5\%, przekazywane są na konto Funduszu Pracy. Przychody Funduszu Pracy pochodzą także z innych źródeł, np. z budżetu państwa i budżetu Unii Europejskiej.

W zasadzie zasiłek dla bezrobotnych przysługuje bezrobotnemu, dla którego nie ma propozycji odpowiedniego zatrudnienia oraz który legitymuje się odpowiednim okresem składkowym. Należy zwrócić uwagę na konstrukcję zastosowaną przez ustawodawcę. W pierwszej kolejności bezrobotny powinien podjąć pracę odpowiadającą jego kwalifikacjom lub wziąć udział w szkoleniu, aby uzyskać taką pracę. Dopiero w przypadku braku takiej pracy lub szkolenia dochodzi do wypłaty świadczenia, co jest ostatecznością.

Zgodnie z definicją zawartą w słowniczku do u.p.z., odpowiednia praca to taka, która spełnia kilka warunków. Po pierwsze musi to być zatrudnienie lub inna praca zarobkowa, które podlegają ubezpieczeniom społecznym. Do wykonywania tej pracy bezrobotny musi mieć wystarczające kwalifikacje, doświadczenie zawodowe lub może ją wykonywać po szkoleniu lub przygotowaniu zawodowym. Ten element znacząco odbiega od standardów międzynarodowych w tym zakresie. Na podstawie konwencji $168 \mathrm{MOP}$, oceniając, czy praca jest odpowiednia dla bezrobotnego, należy brać pod uwagę wiek, staż pracy w dotychczasowym zawodzie, zdobyte doświadczenie, długość okresu bezrobocia, sytuację na rynku pracy, wpływ nowego zatrudnienia na sytuację rodzinną i osobistą. Polski ustawodawca przyjął koncepcję „wystarczających kwalifikacji”, która może prowadzić do degradacji zawodowej bezrobotnego poprzez nakładanie na niego obowiązku podjęcia zatrudnienia lub innej pracy zarobkowej poniżej jego kwalifikacji25. Kolejnym elementem jest stan zdrowia bezrobotnego, który musi pozwalać mu na wykonywanie tej pracy. Nie chodzi tu już o ogólną zdolność do wykonywania pracy, ale o szczególną zdolność do jej wykonywania. Nie bez znaczenia jest

21 Tekst jedn.: Dz. U. 1998, nr 21, poz. 94, ze zm.

22 W. Sanetra, op. cit., s. 86-87.

23 U. Jackowiak, S. DALKa, Dopuszczalność egzekucji z zasiłków dla bezrobotnych, „Praca i Zabezpieczenie Społeczne" 1992, nr 7, s. 60.

24 Por. Uchwała Sądu Najwyższego z dnia 30 kwietnia 1991 r., III CZP 10/91, OSN 1991, nr 8/9, poz. 101.

25 M. WŁodarczyk, Pojęcie odpowiedniego zatrudnienia w ustawie o zatrudnieniu i przeciwdziałaniu bezrobociu, „Studia Prawno-Ekonomiczne” 1999, T. LIX, s. 41. 
także miejsce wykonywania pracy. „Odpowiednia praca” to taka, do której dojazd i powrót nie przekraczają dziennie 3 godzin łącznie. Ostatnim elementem tej definicji jest wysokość wynagrodzenia - bezrobotny nie musi godzić się na podjęcie pracy, za którą uzyska wynagrodzenie niższe niż minimalne wynagrodzenie za pracę w przeliczeniu na pełen wymiar czasu pracy.

$Z$ powyższego wynika, że odpowiednia praca nie jest koniecznie pracą w pełnym wymiarze czasu pracy, mimo że bezrobotny jest gotowy do podjęcia zatrudnienia w pełnym wymiarze czasu pracy. Nie jest także pracą wykonywaną w ramach umowy o dzieło, ponieważ od tej umowy co do zasady potrącana jest jedynie zaliczka za podatek dochodowy, więc nie podlega ona ubezpieczeniom społecznym ${ }^{26}$.

Jak wskazano, aby uzyskać prawo do zasiłku, bezrobotny musi wykazać, że ma staż wymagany do nabycia prawa do zasiłku dla bezrobotnych. Okresy, które są wliczane do tego stażu ustawodawca podzielił na dwie grupy: pierwsza jest związana $z$ aktywnością zawodową bezrobotnego, druga obejmuje okresy zrównane z aktywnością zawodową. Okresy z obu grup podlegają sumowaniu, a bezrobotny nabywa prawo do zasiłku, gdy suma tych okresów wyniesie co najmniej 365 dni w ciągu 18 miesięcy poprzedzających dzień rejestracji w powiatowym urzędzie pracy.

Wśród okresów aktywności zawodowej ustawodawca wskazał w pierwszej kolejności zatrudnienie. Okres zatrudnienia będzie liczony do stażu, od którego zależy zasiłek dla bezrobotnych, pod warunkiem, że bezrobotny otrzymywał za pracę wynagrodzenie w kwocie co najmniej minimalnego wynagrodzenia, od którego istniał obowiązek opłacania składki na Fundusz Pracy. Do tego okresu nie są jednak zaliczane urlopy bezpłatne, które trwały dłużej niż 30 dni. Ustawodawca związał z umową o pracę nakładczą obowiązek uzyskiwania dochodu w wysokości co najmniej minimalnego wynagrodzenia za pracę; nie przewiduje się tutaj obowiązku odprowadzania składek na Fundusz Pracy, jak to ma miejsce w przypadku zatrudnienia. Natomiast podstawa wymiaru składek na ubezpieczenia społeczne i Fundusz Pracy w kwocie co najmniej minimalnego wynagrodzenia za prace jest warunkiem doliczenia do okresu warunkującego nabycie zasiłku dla bezrobotnych w przypadku świadczenia usług na podstawie umowy agencyjnej, umowy zlecenia lub innej z umów o świadczenie usług, do których mają zastosowanie przepisy o zleceniu, prowadzenia pozarolniczej działalności lub współpracy przy jej prowadzeniu oraz wykonywania pracy w charakterze członka w rolniczej spółdzielni produkcyjnej, spółdzielni kółek rolniczych lub spółdzielni usług rolniczych. Pomijając wszystkie wskazane wyżej przypadki, ustawodawca zdecydował także,

26 Wyjątek stanowi umowa zawarta z pracodawcą, z którym wykonawca pozostaje w stosunku pracy, lub jeżeli w ramach takiej umowy wykonuje pracę na rzecz pracodawcy, z którym pozostaje w stosunku pracy, a umowa ta jest zawarta z osobą trzecią (art. 8 ust 2a ustawy z dnia 13 października 1998 r. o systemie ubezpieczeń społecznych, tekst jedn.: Dz. U. 2009, nr 205, poz. 1585, ze zm.) i art. 104 ust. 1 pkt. 1 lit c u.p.z. 
że do stażu warunkującego nabycie świadczenia dla bezrobotnych będzie doliczany każdy okres zatrudnienia, pełnienia służby lub wykonywania innej pracy zarobkowej - pod warunkiem, że od wynagrodzenia czy uzyskiwanego dochodu istniał obowiązek opłacania składki na Fundusz Pracy.

W drugiej grupie okresów wliczanych do stażu niezbędnego do nabycia prawa do zasiłku dla bezrobotnych są zdarzenia zrównane z okresami aktywności zawodowej. W pierwszym rzędzie do tego okresu ustawodawca zaliczył okresy związane z wykonywaniem obowiązku wojskowego wobec państwa ${ }^{27}$. Do okresu, od którego zależy nabycie prawa do zasiłku dla bezrobotnych zostały także zaliczone okresy pełnienia służby w charakterze funkcjonariusza: Policji, Agencji Bezpieczeństwa Wewnętrznego, Agencji Wywiadu, Służby Kontrwywiadu Wojskowego, Służby Wywiadu Wojskowego, Centralnego Biura Antykorupcyjnego, Straży Granicznej, Biura Ochrony Rządu, Państwowej Straży Pożarnej i Służby Więziennej. Kolejną okolicznością zaliczaną do „stażu zasiłkowego” jest urlop wychowawczy, który jest regulowany art. 186 i n. k.p. Następnie ustawodawca wskazał pobieranie renty szkoleniowej i renty z tytułu niezdolności do pracy lub służby w charakterze funkcjonariusza, o której była mowa wyżej. Do stażu warunkującego zasiłek należy także dodać okresy pobierania zasiłku chorobowego, macierzyńskiego, zasiłku w wysokości zasiłku macierzyńskiego lub świadczenia rehabilitacyjnego, które były pobierane po ustaniu zatrudnienia, wykonywania innej pracy zarobkowej albo zaprzestaniu prowadzenia pozarolniczej działalności gospodarczej. Jedynym warunkiem zaliczenia tych okresów jest faktyczne pobieranie tych świadczeń oraz fakt, że podstawą ich obliczenia było co najmniej minimalne wynagrodzenie za pracę. Do 365 dni doliczane są także okresy, za które przyznano bezrobotnemu odszkodowanie z tytułu niezgodnego z przepisami rozwiązania przez pracodawcę stosunku pracy lub stosunku służbowego.

Od nowelizacji ustawy o zatrudnieniu i przeciwdziałaniu bezrobociu (poprzedniczki u.p.z.) z dnia 22 grudnia 1995 r. $^{28}$ przyjęto zasadę kwotowego ustalania wysokości zasiłku, która jest kontynuowana do dnia dzisiejszego. Pamiętać jednak trzeba, że wysokość zasiłku waloryzowana jest z dniem 1 czerwca każdego roku o średnioroczny wskaźnik wzrostu cen towarów i usług konsumpcyjnych w porównaniu z rokiem poprzednim. W związku z tym nie dochodzi do zmiany wysokości świadczenia, jeżeli wskaźnik ten nie zmienił się lub nawet się zmniejszył. Od 1 stycznia 2010 r. ${ }^{29}$ zasiłek dla bezrobotnych wypłacany jest w pierwszych trzech miesiącach pozostawania bez pracy w wyższej wysokości, a następnie jest obniżany. Zmianę tę należy oceniać bardzo pozytywnie, ponieważ

${ }^{27}$ Na przykład zasadnicza służba wojskowa, przeszkolenie wojskowe, służba przygotowawcza, służba kandydacka, ćwiczenia wojskowe.

${ }_{28}$ Dz. U. nr 5, poz. 34.

29 Ustawa z dnia 19 grudnia 2008 r. o zmianie ustawy o promocji zatrudnienia i instytucjach rynku pracy oraz o zmianie niektórych innych ustaw, Dz. U. 2009, nr 6, poz. 33. 
istotnie wzmocniła funkcję motywacyjną zasiłku dla bezrobotnych ${ }^{30}$. W obecnym stanie prawnym ${ }^{31}$ zasiłek podstawowy wynosi $831,10 \mathrm{zł}$, a po trzech miesiącach zostaje zmniejszony do kwoty 652,60 zł. Wskazane kwoty stanowią tzw. zasiłek podstawowy, który przysługuje osobom, legitymującym się „okresem uprawniającym do zasiłku” dłuższym niż 5 lat, ale nie przekraczającym 20 lat. Natomiast bezrobotnemu, w przypadku którego okres uprawniający do zasiłku jest krótszy niż 5 lat przysługuje tzw. zasiłek obniżony, zaś temu, dla którego ten okres jest dłuższy niż 20 lat - tzw. zasiłek podwyższony. Zasiłek obniżony stanowi $80 \%$ zasiłku podstawowego $(664,90 z ł$ w okresie pierwszych trzech miesięcy i 522,10zł w okresie kolejnych miesięcy posiadania prawa do zasiłku), zaś podwyższony - $120 \%$ zasiłku podstawowego $(997,40 z ł$ w okresie pierwszych trzech miesięcy i 783,20zł w okresie kolejnych miesięcy posiadania prawa do zasiłku).

Kluczowe znaczenie dla określenia wysokości zasiłku ma ustalenie, czym jest „okres uprawniający do zasiłku”, od którego zależy wysokość przysługującego świadczenia. Zgodnie z art. 72 ust. 2 u.p.z., wliczane są do niego okresy aktywności zawodowej wymienione w art. 71 ust. 1 pkt 2 oraz wszystkie okresy z art. 71 ust. 2, z pominięciem pkt 3 tego ustępu, które były wskazane wyżej. Dodatkowo do „okresu uprawniającego do zasiłku” ustawodawca zaliczył także inne okresy niż te, które są okresami warunkującymi nabycie prawa do zasiłku. Należą do nich $\mathrm{m}$.in. okresy pobierania gwarantowanego zasiłku okresowego, zatrudnienia na podstawie umowy o pracę w celu przygotowania zawodowego młodocianych oraz opieki nad dzieckiem przed wprowadzeniem urlopu wychowawczego.

Okres pobierania zasiłku dla bezrobotnych jest uzależniony od stopy bezrobocia na obszarze zamieszkania bezrobotnego w dniu 30 czerwca roku poprzedzającego dzień nabycia prawa do tego świadczenia. W istocie takie rozwiązanie należy taktować jako przejaw socjalnej polityki państwa. Na terenach, gdzie bezrobocie jest większe, a w związku z tym trudniej znaleźć zatrudnienie, bezrobotny będzie otrzymywał zasiłek przez okres dłuższy niż bezrobotny mieszkający na terenie o niższym wskaźniku bezrobocia. Ustawa przewiduje również, że długość okresu pobierania zasiłku może być także podyktowana sytuacją rodzinną lub zawodową bezrobotnego. Prawo do pobierania zasiłku dla bezrobotnych przez 6 miesięcy mają osoby mieszkające na terenie powiatu, w którym stopa bezrobocia w dniu 30 czerwca roku poprzedzającego nie przekroczyła $150 \%$ przeciętnej stopy bezrobocia w kraju lub 12 miesięcy, jeżeli stopa bezrobocia przekroczyła $150 \%$ przeciętnej stopy bezrobocia w kraju. Dodatkowo zasiłek przez 12 miesięcy będzie przysługiwał bezrobotnemu, który ukończył 50 lat i posiada co najmniej 20-letni okres uprawniający do zasiłku oraz bezrobotnemu, który ma na utrzymaniu jedno lub więcej dzieci, poniżej 15 roku życia, a małżonek jest bezrobotny i utracił prawo do zasiłku dla bezrobotnych w związku z wyczerpaniem okresu jego pobierania po nabyciu prawa do zasiłku dla bezrobotnego.

${ }^{30}$ E. KWIATKowski, Czy zasiłki dla bezrobotnych generują wzrost bezrobocia? Stare dylematy w świetle nowych badań, „Dialog” 2011, nr 1, s. 127.

31 Stan na 1 czerwca 2014 r. 
Z przeprowadzonych rozważań wynika wprost, że fakt utraty zatrudnienia to za mało, aby nabyć status bezrobotnego. Szereg przesłanek znajdujących się w drugiej części definicji wskazuje, że główną okolicznością wpływającą na nabycie tego statusu jest brak źródeł utrzymania. W związku z tym wydaje się, że polski ustawodawca nie czerpie ani z doświadczeń innych państw, ani z dorobku doktryny w tym zakresie. Normatywne pojęcie bezrobotnego jest bardziej adekwatne do wypłacania świadczeń z pomocy społecznej niż do systemu wypłaty zasiłków dla bezrobotnych, który zawiera wiele elementów modelu ubezpieczeniowego ${ }^{32}$. W związku z tym należy postulować, aby na potrzeby polityki rynku pracy została stworzona nowa definicja bezrobotnego, która byłaby bardziej adekwatna do oczekiwań i potrzeb związanych z łagodzeniem skutków bezrobocia, także poprzez wypłatę świadczeń.

Warto zauważyć, że obecnie ${ }^{33}$ 11,9\% ludności aktywnej zawodowo w Polsce stanowią bezrobotni (w woj. warmińsko-mazurskim jest to nawet 18,6\%). Dodatkowo $86,9 \%$ bezrobotnych zarejestrowanych w powiatowych urzędach pracy nie ma prawa do zasiłku. Jest to bardzo duża liczba, biorąc pod uwagę fakt, że 82,5\% zarejestrowanych bezrobotnych wykonywało wcześniej pracę zarobkową, jednak mimo to nie udało im się spełnić wszystkich przesłanek nabycia prawa do zasiłku dla bezrobotnych. Oznacza to, że zaledwie niewielka liczba bezrobotnych ma zagwarantowane świadczenie z tytułu braku pracy. Taki stan rzeczy powoduje, że postulaty zawarte $w$ encyklice nie są realizowane przez polskiego ustawodawcę. Większość bezrobotnych musi poszukiwać wsparcia w postaci świadczeń z pomocy społecznej.

Brak uzależnienia wysokości zasiłku dla bezrobotnych od poprzedniego wynagrodzenia jest kolejnym poważnym mankamentem polskiego systemu zabezpieczenia społecznego na wypadek bezrobocia. Obecne rozwiązania przeczą funkcji kompensacyjnej tego świadczenia, które powinno zastępować utracony dochód w związku z niemożnością wykonywania pracy, więc powinno pozostawać w relacji $z$ wynagrodzeniem poprzedzającym okres bezrobocia ${ }^{34}$. W takim przypadku z pewnością polski system wypłaty zasiłku dla bezrobotnych zostałby zbliżony do wzorca zawartego w encyklice Laborem exercens papieża Jana Pawła II.

32 Zob. K. JAWORSKA, Charakter prawny zasiłku dla bezrobotnych, [w:] Bezrobocie i polityka zatrudnienia, red. Z. Góral, Warszawa 2013, s. 91 i n.

33 Dane statystyczne pochodzą z Miesięcznej informacji o bezrobociu rejestrowanym w Polsce w lipcu 2014 roku, http://stat.gov.pl/obszary-tematyczne/praca-wynagrodzenia/bezrobocie-stopa-bezrobocia/miesieczna-informacja -o-bezrobociu-rejestrowanym-w-polsce-w-lipcu-2014-roku,1,30.html [dostęp: 22.09.2014].

34 Z. Góral, Prawo do pracy. Studium prawa polskiego w świetle porównawczym, Łódź 1994, s. 200 . 